SUBJECT AREAS:

ECOLOGICAL

NETWORKS

ECOSYSTEM ECOLOGY

FOREST ECOLOGY

Received

31 July 2013

Accepted

13 February 2014

Published

28 February 2014

Correspondence and requests for materials should be addressed to G.R.Y. (yugr@igsnrr. ac.cn)

\title{
abundance in forest ecosystems along a large transect in eastern China
}

\author{
Wenping Sheng, Guirui Yu, Huajun Fang, Yingchun Liu, Qiufeng Wang, Zhi Chen \& Li Zhang
}

Key Laboratory of Ecosystem Network Observation and Modeling, Institute of Geographic Sciences and Natural Resources Research, Chinese Academy of Sciences, Beijing 100101, PR China.

The regional determining factors underlying inter- and intra-site variation of ${ }^{15} \mathrm{~N}$ natural abundance in foliage, $\mathrm{O}$ horizon and mineral soil were investigated in eastern China. ${ }^{15} \mathrm{~N}$ natural abundance values for these forest ecosystems were in the middle of the range of values previously found for global forest ecosystems. In contrast to commonly reported global patterns, temperate forest ecosystems were significantly more ${ }^{15} \mathrm{~N}$-enriched than tropical forest ecosystems, and foliage $\delta^{15} \mathrm{~N}$ was negatively correlated with increasing mean annual temperature and net soil $\mathrm{N}$ mineralisation in eastern China. Tight $\mathrm{N}$ cycling in forest ecosystems and the use of atmospheric $\mathrm{N}$ deposition by trees might underlie the $\delta^{15} \mathrm{~N}$ distribution patterns in eastern China. The existence of mycorrhizal fungi and root distribution profiles in the soil may also influence the ${ }^{15} \mathrm{~N}$ natural abundance patterns in forest ecosystems of eastern China.

T he natural nitrogen stable isotope $\left({ }^{15} \mathrm{~N}\right)$ technique has been widely used in ecological studies of $\mathrm{N}$ cycling ${ }^{1,2}$ because the ${ }^{15} \mathrm{~N}$ natural abundance values $\left(\delta^{15} \mathrm{~N}\right)$ of plant and soil samples are the net results of many biogeochemical processes that can cause discrimination in ${ }^{15} \mathrm{~N}^{3}$. It is feasible to use ${ }^{15} \mathrm{~N}$ to investigate $\mathrm{N}$ cycling in large areas because the information collected in a single sampling provides direct insight into past $\mathrm{N}$ cycling by providing a record of the net effect of $\mathrm{N}$ transformations. In terrestrial ecosystems, biogeochemical and physiological processes have determined variability in the $\delta^{15} \mathrm{~N}$ of plants and soil. Though $\mathrm{N}$ isotope fractionation during $\mathrm{N}$ mineralisation is small, soil $\mathrm{N}$ processes, such as ammonia volatilisation, nitrification and denitrification, involve fairly large $\mathrm{N}$ isotope effects; the preferential leaching and gaseous loss of the lighter ${ }^{14} \mathrm{~N}$ leaves the soil enriched in ${ }^{15} \mathrm{~N}^{4}$. The factors that affect $\delta^{15} \mathrm{~N}$ in plants mainly include the source of $\mathrm{N}$ and the forms of soil $\mathrm{N}$ used ${ }^{4}$.Concentrations of $\mathrm{NH}_{4}{ }^{+}$and $\mathrm{NO}^{3-}$ in the soil affect the isotope fractionation during $\mathrm{N}$ uptake by plants $\mathrm{s}^{5,6}$. Furthermore, mycorrhizal fungi supply depleted ${ }^{15} \mathrm{~N}$ sources to their host plants. According to a global study, mycorrhizal plants were found to be depleted by $2.0-5.9 \%$ relative to nonmycorrhizal plants with respect to foliage $\delta^{15} \mathrm{~N}^{7}$. The use of atmospherically deposited $\mathrm{N}$ can also decrease the $\delta^{15} \mathrm{~N}$ value of plants ${ }^{8,9}$.

Studies of $\delta^{15} \mathrm{~N}$ have been conducted in many regions around the world, and some characteristics of ${ }^{15} \mathrm{~N}$ distribution, as well as relationships between $\delta^{15} \mathrm{~N}$ and environmental factors, have been found. Studies compiling worldwide data indicate that ${ }^{15} \mathrm{~N}$ is more enriched in tropical forest ecosystems than in temperate forest ecosystems $^{10}$, and soil and plant $\delta^{15} \mathrm{~N}$ are positively correlated with MAT (mean annual temperature) and negatively correlated with MAP (mean annual precipitation) $)^{7,11}$.

However, the data used in these studies are mainly drawn from field investigations in North America, South America, Europe, Africa, and Australia. Recently, a few studies from eastern Asia have shown inconsistencies in the distributions of $\delta^{15} \mathrm{~N}$ and their relationships with climate. For example, negative foliage $\delta^{15} \mathrm{~N}$ data are found in the tropical rainforests of China and Malaysia ${ }^{12,13}$. Furthermore, both positive ${ }^{14}$ and negative ${ }^{8}$ relationships are found between plant $\delta^{15} \mathrm{~N}$ and MAT and MAP in regional studies of eastern Asia. Because of the influence of the eastern Asian monsoon, the climate differs from that in Europe and North America, with apparent latitudinal gradients of temperature and precipitation are found along the North-South Transect of Eastern China $(\mathrm{NSTEC})^{15}$. Moreover, nitrogen deposition forms a tremendous gradient along the NSTEC ${ }^{16}$. The synchronous change of spatial distribution of temperature, moisture, and $\mathrm{N}$ deposition might give a more complicated effect on $\delta^{15} \mathrm{~N}$ patterns in eastern China. In this study, based on a systematic investigation of seven typical forest ecosystems along the NSTEC (Fig. 1), it was our aim to 1) describe variation in $\delta^{15} \mathrm{~N}$ values in the foliage, O horizon, and mineral soil among typical forest ecosystems in China; 2) clarify patterns of $\delta^{15} \mathrm{~N}$ distribution in the forest ecosystems over environmental gradients; 3 ) explore potential key factors and mechanisms contributing to the 
- Sampling sites

$\square \square$ Cold-temperate coniferous forest

$\ldots$ Temperate mixed forest

$\$$ Warm-temperate deciduous broadleaved forest

$\checkmark$ Subtropical evergreen broadleaved forest

$\square /$ Tropical monsoon rain forest

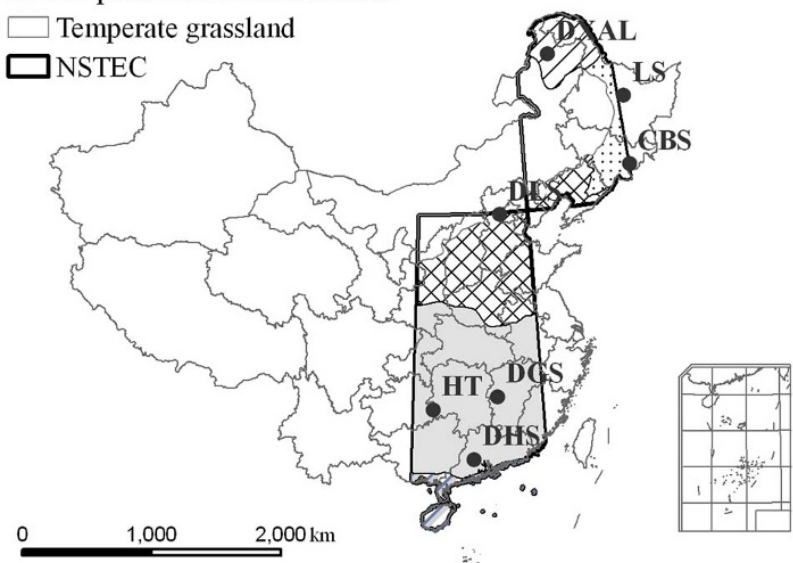

Figure 1 Vegetation regionalisation and sampling sites in eastern China. The NSTEC is coloured and the different colours represent different vegetation types. The full names of the sampling sites are shown in Table 1. *the map is created in the support of arcgis 9.3 (ESRI).

patterns. This study provides new insights into regional patterns of the natural abundance of ${ }^{15} \mathrm{~N}$ isotopes in forest ecosystems in China.

\section{Results}

Frequency distribution of $\delta^{15} \mathrm{~N}$ values in foliage, $\mathrm{O}$ horizons and mineral soils. The relative frequency distributions of $\delta^{15} \mathrm{~N}$ values in foliage, $\mathrm{O}$ horizon and mineral soil samples in natural forest ecosystems along the NSTEC are shown in Fig. 2. Significant differences in $\delta^{15} \mathrm{~N}$ values were observed among the different components of forest ecosystems in eastern China ( $\mathrm{F}=252.68, p$ $<0.001)$. Most foliage samples had negative $\delta^{15} \mathrm{~N}$ values, more than $80 \%$ of the values in O horizon samples were between $-2 \%$ and $2 \%$, and the values of almost all mineral soil samples were between $4 \%$ and $8 \%$. The mean $\delta^{15} \mathrm{~N}$ values in foliage, $\mathrm{O}$ horizon and mineral soil samples were $-1.5 \pm 0.2 \%,-0.9 \pm 0.2 \%$ and $5.1 \pm 0.18 \%$, respectively; thus, in natural forest ecosystems in eastern China, live foliage biomass was depleted of ${ }^{15} \mathrm{~N}$, and mineral soil was enriched with ${ }^{15} \mathrm{~N}$.

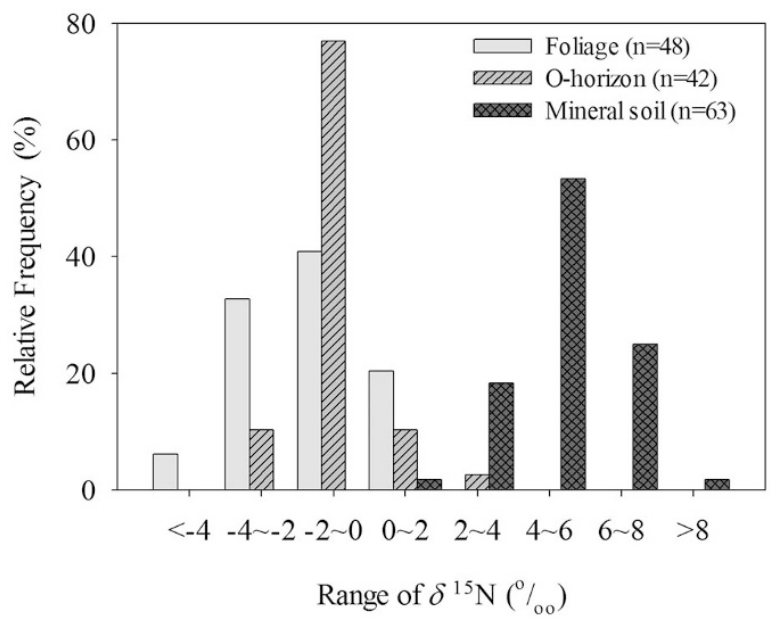

Figure $2 \mid$ Relative frequency of natural $\delta^{15} \mathrm{~N}$ in the foliage, $\mathrm{O}$ horizon, and mineral soil samples.
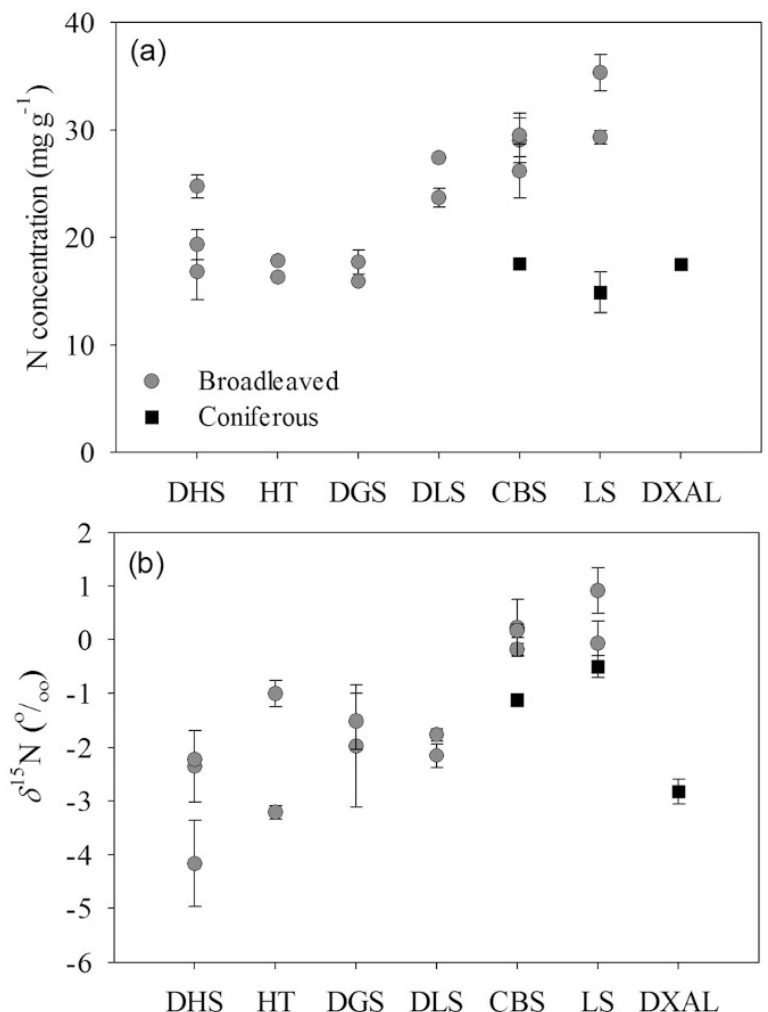

Figure $3 \mid \mathrm{N}$ concentrations and $\delta^{15} \mathrm{~N}$ values of the foliage in typical forest ecosystems in eastern China (sampling sites are arranged such that latitude increases from left to right).

Spatial distribution of $\delta^{15} \mathrm{~N}$. Fig. 3 shows the $\delta^{15} \mathrm{~N}$ values of the foliage sorted according to latitude in eastern China $\left(\mathrm{R}^{2}=0.34, p\right.$ $=0.015$ ), indicating a more regular pattern than the distribution of $\mathrm{N}$ concentrations. The mean values of foliage $\delta^{15} \mathrm{~N}$ increased significantly from $-4.2 \%$ in the DHS subtropical monsoon evergreen broadleaved forest to $0.9 \%$ in the LS temperate coniferous and broadleaved mixed forest. However, the mean values of foliage $\delta^{15} \mathrm{~N}$ decreased to $-2.8 \%$ in the boreal coniferous forest in DXAL. The $\delta^{15} \mathrm{~N}$ values of the $\mathrm{O}$ horizon were slightly greater than the values of the foliage, increasing from $-3.3 \%$ o to $2.6 \%$. Like the foliage, the $\delta^{15} \mathrm{~N}$ values in the $\mathrm{O}$ horizon increased significantly with increasing latitude $\left(\mathrm{R}^{2}=0.30, p=0.043\right)$. However, the statistical significance was weaker between $\delta^{15} \mathrm{~N}$ values in the mineral soil and latitude.

Temperate forest ecosystems were significantly more ${ }^{15} \mathrm{~N}$-enriched than tropical forest ecosystems (Fig. 4). The mean $\delta^{15} \mathrm{~N}$ value for tropical forest foliage was $-2.3 \%$, which was $1.6 \%$ lower than that

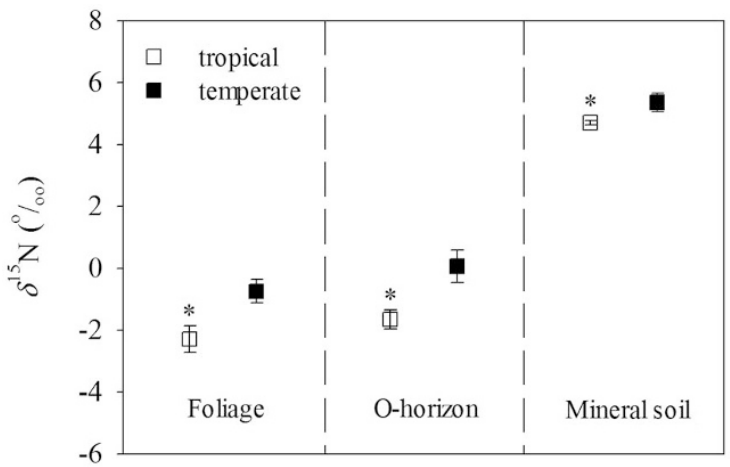

Figure $4 \mid$ Differences in $\delta^{15} \mathrm{~N}$ between temperate and tropical forest ecosystems (statistically significant differences were set as $p<0.05$ ). 
of temperate forest foliage. The range of $\delta^{15} \mathrm{~N}$ values was larger in the organic layer than in the soil mineral layer, and $\delta^{15} \mathrm{~N}$ was $1.7 \%$ and $0.7 \%$ in $\mathrm{O}$ horizon and mineral soil, respectively.

The $\delta^{15} \mathrm{~N}$ values increased with soil depth, and they increased sharply from the $\mathrm{O}$ horizon to the mineral soil. The $\delta^{15} \mathrm{~N}$ values in the O horizon and mineral soil were distinctly different $(\mathrm{F}=363.07$, $p<0.001)$. The range of $\delta^{15} \mathrm{~N}$ values among different sites decreased with increasing soil depth, from $3.9 \%$ in the top sampled layer to $2.2 \%$ at $40 \mathrm{~cm}$ below the ground surface (Fig. 5a). Moreover, the mean $\mathrm{N}$ concentration decreased from the upper $\mathrm{O}$ horizon to the lower mineral soil horizons (Fig. 5b). Similar to the variation in $\delta^{15} \mathrm{~N}$ values, differences in $\mathrm{N}$ concentrations between the $\mathrm{O}$ horizon and mineral soil were significant $(\mathrm{F}=245.31, p<0.001)$.

Effect of environmental variations on $\delta^{\mathbf{1 5}} \mathbf{N}$. There was clear latitudinal zonality in the distribution of environmental factors in eastern China, such as the MAT, MAP, and N deposition (Table 1). It was clear that environmental variation exerts an obvious effect on foliage $\delta^{15} \mathrm{~N}$ values (Fig. 6). However, these effects decreased as the depth increased because the range of soil $\delta^{15} \mathrm{~N}$ values across sites diminished with increasing depth (Fig. 5). Foliage $\delta^{15} \mathrm{~N}$ values were more dramatically influenced by nitrogen deposition than by climate factors. As analysed by step regression, $\mathrm{N}$ deposition was the key environmental variation determining the ${ }^{15} \mathrm{~N}$ distribution in eastern China $(\mathrm{F}=9.775, p=0.007)$.

Foliage $\delta^{15} \mathrm{~N}$ values increased dramatically with increasing $\mathrm{N}$ concentrations in eastern China (Fig. 7a). Similarly, $\mathrm{N}$ concentrations and $\delta^{15} \mathrm{~N}$ values were positively correlated with the $\mathrm{O}$ horizon, although this relationship was not statistically significant. In contrast, $\delta^{15} \mathrm{~N}$ values in the mineral soil exhibited a negative relationship with $\mathrm{N}$ concentrations $\left(\mathrm{R}^{2}=0.199, p=0.043\right)$. However, we detected no pattern in $\delta^{15} \mathrm{~N}$ differences between the upper $(0-10 \mathrm{~cm})$ and lower soil layers $(10-40 \mathrm{~cm})$ of the mineral soil when plotted against the variation of the mineral soil $\mathrm{N}$ concentrations. Thus, the relationship between $\delta^{15} \mathrm{~N}$ and $\mathrm{N}$ concentrations in the soil layers was driven by the soil depth.

Foliage $\delta^{15} \mathrm{~N}$ values decreased significantly with the net soil $\mathrm{N}$ mineralisation rate in eastern China (no data in DGS) (Fig. 7b). However, there was no significant correlation between $\delta^{15} \mathrm{~N}$ values and the net soil $\mathrm{N}$ mineralisation rate in the $\mathrm{O}$ horizon and mineral soil layers in forest ecosystems in eastern China.

\section{Discussion}

A meta-analysis study has indicated that the $\delta^{15} \mathrm{~N}$ values for plant tissues and bulk soils are generally between $-10 \%$ and $+15 \%$ in forest ecosystems ${ }^{17} . \delta^{15} \mathrm{~N}$ values of mature forest ecosystems in eastern China occupied the middle of this range $(-4.2 \%$ o to $8.4 \%$ ). The values of foliage $\delta^{15} \mathrm{~N}$ ranged from $-4.2 \%$ o to $+0.9 \%$, which is less than the average value of foliage $\delta^{15} \mathrm{~N}$ from worldwide studies ${ }^{7,11}$. In agreement with broadly observed patterns ${ }^{18,19}$, foliage and $\mathrm{O}$ horizon samples from mature forest ecosystems in eastern China were significantly depleted in ${ }^{15} \mathrm{~N}$ relative to mineral soils (Fig. 2), and $\delta^{15} \mathrm{~N}$ values increased with soil depth (Fig. 5a). $\delta^{15} \mathrm{~N}$ values in soil surface samples are lower than further down in the soil because litterfall imports ${ }^{15} \mathrm{~N}$-depleted $\mathrm{N}$ onto the soil surface. Another possible explanation of this pattern is that plants discriminate against ${ }^{15} \mathrm{~N}$ during $\mathrm{N}$ uptake ${ }^{19}$. In addition, the enrichment of ${ }^{15} \mathrm{~N}$ in deeper soils may be the result of discrimination against ${ }^{15} \mathrm{~N}$ during mineralisation and the loss of ${ }^{15} \mathrm{~N}$-depleted nitrogen from soils due to root uptake, nitrate leaching and denitrification ${ }^{4,18}$.

$\delta^{15} \mathrm{~N}$ values increased with increasing latitude along the NSETC in eastern China (Fig. 3). However, in contrast to the meta-analysis by Martinelli et al. ${ }^{10}$, temperate forest ecosystems were significantly more ${ }^{15} \mathrm{~N}$-enriched than tropical forest ecosystems (Fig. 4). The average value of foliage $\delta^{15} \mathrm{~N}$ in the subtropical forest ecosystems was negative and approximately $6 \%$ lower than the summarised worldwide value, but it was similar to the value of temperate forest ecosystems in the worldwide synthesis ${ }^{10}$. The average value of foliage $\delta^{15} \mathrm{~N}$ was $-0.7 \%$ in the temperate forest ecosystems in east China, which was $2.1 \%$ higher than the average value from the worldwide data synthesis. The investigation in the Hainan islands, at the south end of the NSTEC, demonstrated that the foliage $\delta^{15} \mathrm{~N}$ there is between $-2.8 \%$ and $-2.0 \%{ }^{13}$, similar to the values in our study. Nevertheless, in the tropical forest ecosystem in Malaysia, the foliage $\delta^{15} \mathrm{~N}$ shows an even lower negative value ${ }^{12}$. Our results show that the foliage $\delta^{15} \mathrm{~N}$ values varied significantly with climate in eastern China (Fig. 6). In contrast to the global results indicating that foliage $\delta^{15} \mathrm{~N}$ values increase with decreasing MAP and increasing MAT $^{7,11}$, foliage $\delta^{15} \mathrm{~N}$ values were negatively correlated with both MAP and MAT in forest ecosystems along the transect in eastern China (Fig. 6). We propose several potential mechanisms to explain the $\delta^{15} \mathrm{~N}$ patterns along the NSTEC.

First, the foliage $\delta^{15} \mathrm{~N}$ values may be controlled by the available inorganic $\mathrm{N}$ sources and the ratio of $\mathrm{NO}_{3}{ }^{-}$to $\mathrm{NH}_{4}{ }^{+}$in soils in eastern China. Higher temperatures promote microbial activity and enhance both mineralisation and nitrification rates. Net $\mathrm{N}$ mineralisation rates are generally higher in subtropical and tropical forest soils than in temperate forest soils, and nearly all nitrogen that is mineralised in these systems is immediately nitrified. For example, soil $\mathrm{NH}_{4}{ }^{+}$ accounts for more than $88 \%$ of the total inorganic $\mathrm{N}$ in the forest ecosystem at $\mathrm{CBS}^{20}$, while nitrification represents close to $80 \%$ of the net mineralisation in subtropical monsoon forest ecosystems at $\mathrm{DHS}^{21}$. Nitrification is associated with fairly large isotope effects ${ }^{22}$, and some studies have reported that ${ }^{15} \mathrm{~N}$ in $\mathrm{NH}_{4}{ }^{+}$is more enriched

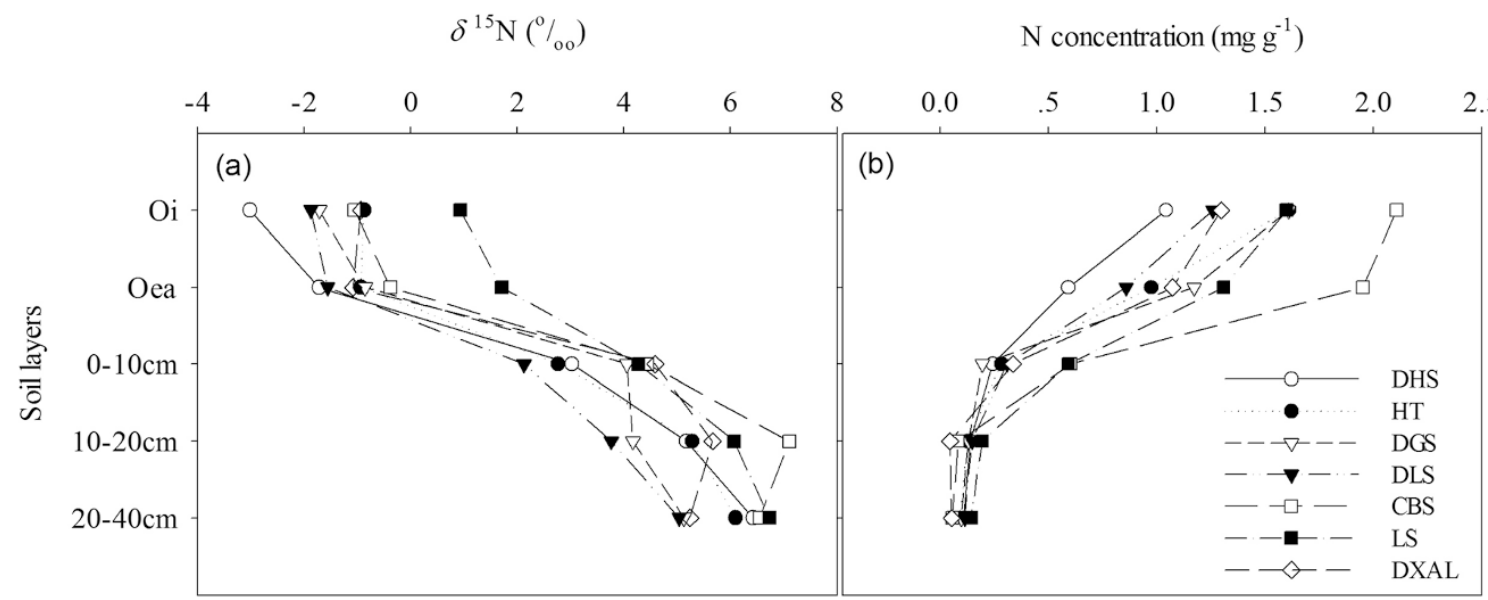

Figure 5 | Variations in $\delta^{15} \mathrm{~N}$ values and $\mathrm{N}$ concentrations from the $\mathrm{O}$ horizon to a $40 \mathrm{~cm}$ mineral soil depth at the different sampling sites. 


\begin{tabular}{|c|c|c|c|c|c|c|c|c|c|}
\hline $\begin{array}{l}\text { Forest research } \\
\text { station }\end{array}$ & Location & $\begin{array}{l}\text { Elevation } \\
(\mathrm{m})\end{array}$ & $\begin{array}{l}\mathrm{MAT}^{a} \\
\left({ }^{\circ} \mathrm{C}\right)\end{array}$ & $\begin{array}{l}M^{M A P b} \\
(\mathrm{~mm})\end{array}$ & $\begin{array}{c}\text { ANDF }^{c} \\
\left(\mathrm{~kg} N \mathrm{ha}^{-1} \mathrm{a}^{-1}\right)\end{array}$ & $\begin{array}{c}\text { ANNM }^{d} \\
\left(\mathrm{~kg} N \mathrm{ha}^{-1} \mathrm{a}^{-1}\right)\end{array}$ & Soil type & Forest type & $\begin{array}{c}\text { Dominant broadleaved } \\
\text { species }\end{array}$ \\
\hline $\begin{array}{l}\text { Dagangshan } \\
\text { (DGS) }\end{array}$ & $27.5^{\circ} \mathrm{N}, 114.5^{\circ} \mathrm{E}$ & 652 & 17.0 & 1633.7 & 9.0 & 59.5 & Yellow soil & $\begin{array}{l}\text { Subtropical } \\
\text { evergreen } \\
\text { broadleaved } \\
\text { forest }\end{array}$ & $\begin{array}{l}\text { Schima argentea, } \\
\text { Elaeocarpus sylvestris }\end{array}$ \\
\hline $\begin{array}{l}\text { Changbaishan } \\
\text { (CBS) }\end{array}$ & $42.4^{\circ} \mathrm{N}, 128.1^{\circ} \mathrm{E}$ & 738 & 3.0 & 714.1 & 2.7 & 63.2 & $\begin{array}{l}\text { Dark brown } \\
\text { forest soil }\end{array}$ & $\begin{array}{l}\text { Temperate mixed } \\
\text { forest }\end{array}$ & $\begin{array}{l}\text { Pinus koraiensis, Tilia } \\
\text { amurensis, Quercus } \\
\text { mongolica, Fraxinus } \\
\text { mandshurica }\end{array}$ \\
\hline Liangshui (LS) & $47.1^{\circ} \mathrm{N}, 127.5^{\circ} \mathrm{E}$ & 703 & 1.1 & 663.6 & 7.0 & 49.3 & $\begin{array}{r}\text { Dark brown } \\
\text { forest soil }\end{array}$ & $\begin{array}{l}\text { Temperate mixed } \\
\text { forest }\end{array}$ & $\begin{array}{l}\text { Pinus koraiensis, Betula } \\
\text { costata, Tilia } \\
\text { amurensis }\end{array}$ \\
\hline $\begin{array}{l}\text { Daxinganling } \\
\text { (DXAL) }\end{array}$ & $50.8^{\circ} \mathrm{N}, 121.5^{\circ} \mathrm{E}$ & 898 & -5.6 & 525.8 & 1.3 & 71.7 & $\begin{array}{l}\text { Brown } \\
\text { coniferous } \\
\text { forest soil }\end{array}$ & $\begin{array}{l}\text { Boreal coniferous } \\
\text { forest }\end{array}$ & Larix gmelinii \\
\hline
\end{tabular}

than that in $\mathrm{NO}_{3}{ }^{-}$in soil solutions $\mathrm{s}^{20,23} \cdot{ }^{15} \mathrm{~N}$ enriched $\mathrm{NH}_{4}{ }^{+}$is available for absorption by plants before it has been nitrified in $\mathrm{N}$-limited conditions ${ }^{24}$ in the north of the NSTEC. The ${ }^{15} \mathrm{~N}$-depleted $\mathrm{NO}_{3}{ }^{-}$ would also be used by plants rather than left from the ecosystem in the south of the NSTEC because the N cycle is in stage 1 according to the concept of $\mathrm{N}$ saturation ${ }^{25}$. Therefore, the foliage $\delta^{15} \mathrm{~N}$ increased from south to north along the NSTEC and was negatively correlated with the increasing MAT (Fig. 6) and net soil $\mathrm{N}$ mineralisation (Fig. 7).

Second, in recent decades, the biogeochemical cycling of nitrogen has been fundamentally changed by atmospheric $\mathrm{N}$ deposition as a result of fossil fuel consumption, the emission of industrial waste gases, excessive fertiliser application, and rapid development of animal husbandry ${ }^{26}$. Fossil fuel emissions have depleted ${ }^{15} \mathrm{~N}$ in the nitrate deposition over the past decade, as revealed by the $\delta^{15} \mathrm{~N}$ values in a 100 -m-long ice core ${ }^{27}$. Because ammonia volatilisation is a highly fractionating process and produces much ${ }^{15} \mathrm{~N}$-depleted $\mathrm{NH}_{3}{ }^{27}$, the $\delta^{15} \mathrm{~N}$ values of deposited ammonium are usually negative. For instant, Xiao \& $\mathrm{Liu}^{28}$ reported that the mean $\delta^{15} \mathrm{~N}$ values of nitrate and ammonium in wet deposition at seven different sites around the world (including the Chinese city Guiyang) were $-1.9 \%$ and $-5.0 \%$, respectively. Studies of five sites in the North China Plains found that the mean values of nitrate and ammonium in rainfall were $-2.5 \%$ and $-1.2 \%$, respectively ${ }^{29}$. In Guangzhou, the provincial capital of Guangdong, the annual values of nitrate and ammonium in wet deposition were $-0.7 \%$ and $-7.3 \%$, respectively ${ }^{30}$. The moss $\delta^{15} \mathrm{~N}$, which was assumed to be an integrator of the isotopic signatures of atmospheric $\mathrm{N}$ sources, also indicated that the $\delta^{15} \mathrm{~N}$ of
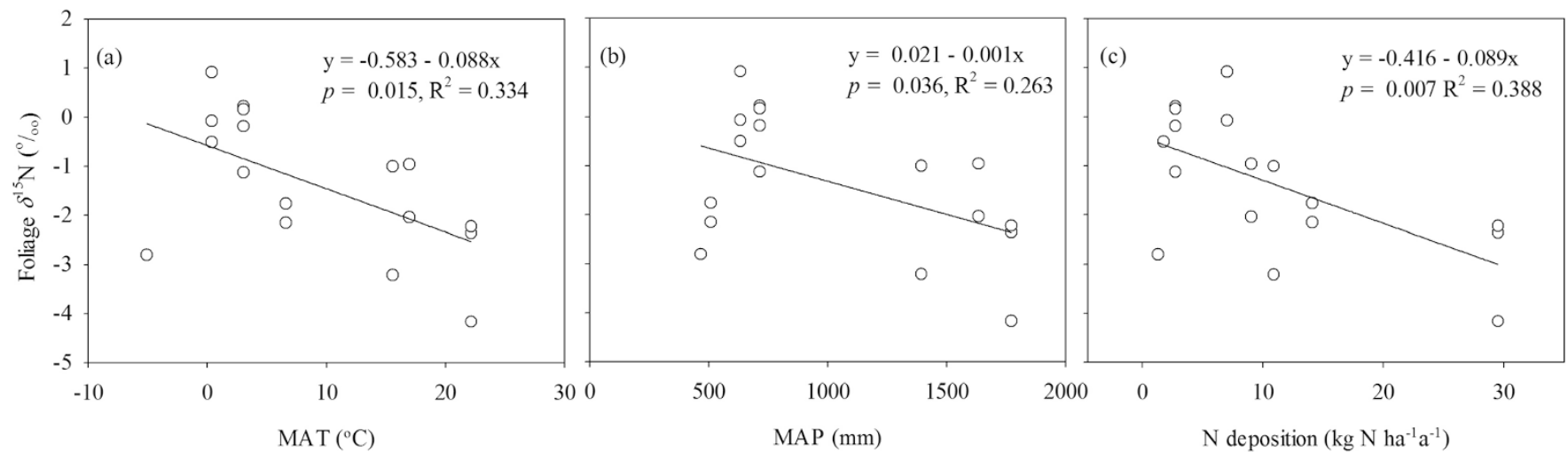

Figure 6 Relationships between foliage $\delta^{15} \mathrm{~N}$ values and environmental factors (temperature, precipitation, and $\mathrm{N}$ deposition). 

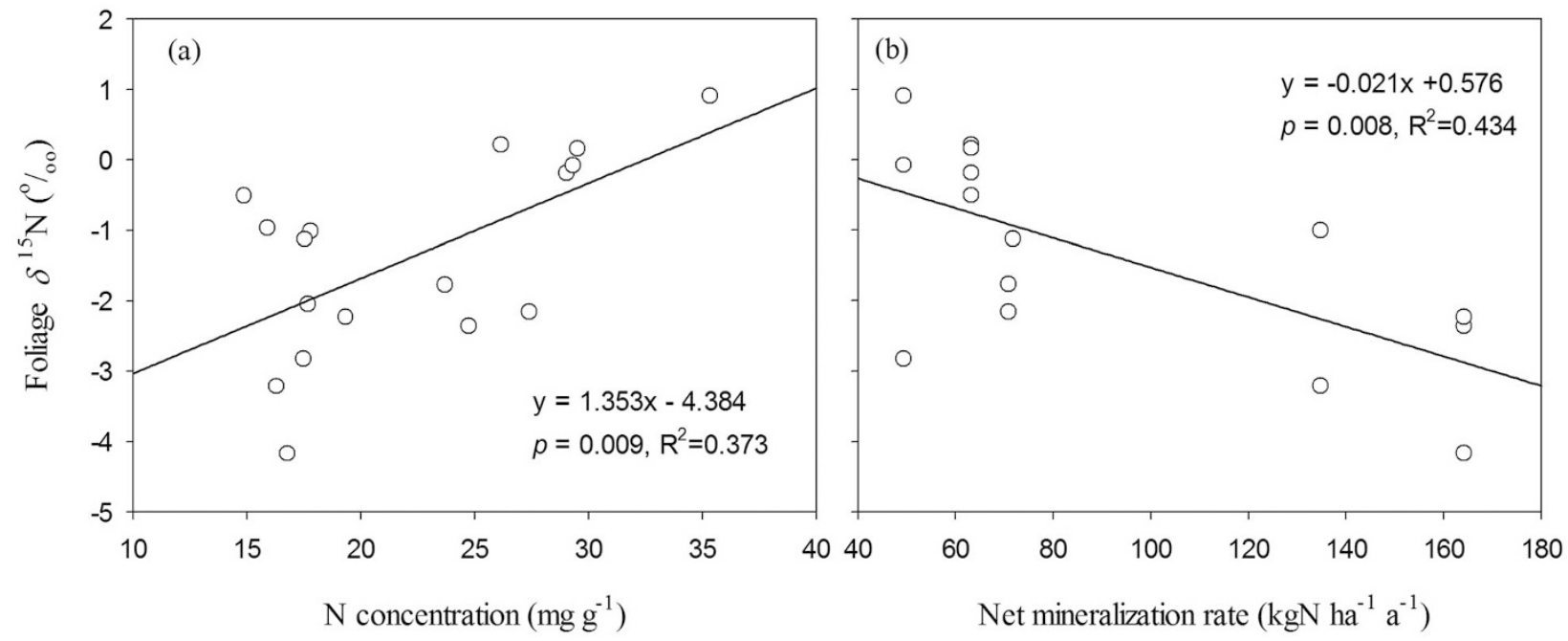

Figure $7 \mid$ Relationships between foliage $\delta^{15} \mathrm{~N}$ values, $\mathrm{N}$ concentrations and net $\mathrm{N}$ mineralization.

atmospheric $\mathrm{N}$ in the urban areas, rural areas and forests of southern China were, on average $-7.5 \%$, $-3.4 \%$ and $-0.8 \%$, respectively ${ }^{31}$.

Given that the $\mathrm{N}$ deposition increased more than threefold from north to south in eastern China and that ammonium is the dominant form of $\mathrm{N}$ deposition in eastern China ${ }^{16}$, it appears that the ${ }^{15} \mathrm{~N}$ depleted $\mathrm{N}$ input in tropical forest ecosystems is higher than that in temperate forest ecosystems. Plants grown in areas of heavier atmospheric $\mathrm{N}$ deposition have much lower $\delta^{15} \mathrm{~N}$ values, likely as a result of absorbing more ${ }^{15} \mathrm{~N}$-depleted inorganic $\mathrm{N}$ sources through their roots or stomata ${ }^{9,25}$. In our study, the influence of $\mathrm{N}$ deposition on foliage $\delta^{15} \mathrm{~N}$ patterns is reflected by the significant negative relationship between the foliage $\delta^{15} \mathrm{~N}$ values and atmospheric nitrogen deposition (Fig. 6). This negative relationship has also been observed in a forest ecosystem along an urban-rural gradient ${ }^{32}$. The intensified $\mathrm{N}$ deposition is also thought to be the reason why the relationship between $\delta^{15} \mathrm{~N}$ and MAT along a grass transect in eastern China is inconsistent with the global pattern ${ }^{8}$. The difference in atmospheric $\mathrm{N}$ deposition is likely to be a crucial contributor to the pattern of foliage ${ }^{15} \mathrm{~N}$ signatures in eastern China. $\delta^{15} \mathrm{~N}$ data from tree rings show a significant decline from $2.1 \%$ to $-1.5 \%$ over the past 60 years, giving further evidence that $\mathrm{N}$ deposition decreased $\delta^{15} \mathrm{~N}$ patterns along with the available $\mathrm{N}^{25}$. However, in contrast to Europe and America ${ }^{33-35}$, the history of ecosystem in eastern China suffering anthropogenically elevated $\mathrm{N}$ deposition is short, for the reason that enormous development of the economy began in 1980s in China. The high $\mathrm{N}$ deposition has not enriched ${ }^{15} \mathrm{~N}$ by increasing $\mathrm{N}$ losses in $\mathrm{N}$-rich sites. Therefore, the impact of $\mathrm{N}$ deposition flux to the ${ }^{15} \mathrm{~N}$ natural abundance remains negative in the natural ecosystems in China.

Third, the existence of mycorrhizal fungi may have distorted the vertical pattern in the surface soil and depleted foliage ${ }^{15} \mathrm{~N}$ at DXAL (Fig. 3,5 ). The growth of trees and shrubs is often strongly N-limited because soils typically contain large amounts of organic $\mathrm{N}$ and low concentrations of inorganic $\mathrm{N}^{36,37}$. One way for plants to relive this $\mathrm{N}$ limitation is to take up amino acids from the soil through symbiotic fungi ${ }^{18,38}$. The $\mathrm{N}$ transfer from mycorrhizal fungi to their hosts is ${ }^{15} \mathrm{~N}$ depleted because of fractionation during metabolic processes and selective retention of specific $\mathrm{N}$ compounds by the fungus, as evidenced by fungal $\mathrm{N}$ enrichment of 3-11\%o relative to the host plant $\mathrm{N}^{4,19}$. The existence of mycorrhizal fungi could explain the low foliage $\delta^{15} \mathrm{~N}$ and the distorted vertical pattern in the surface soil at DXAL. The presence of mycorrhizal fungi was shown to be one of the most important reasons for the enrichment of foliage $\delta^{15} \mathrm{~N}$ from south to north along a transect in forest ecosystems in Finland ${ }^{3}$. Analyses based on worldwide data also indicate that plants infected by mycorrhizal fungi are depleted in foliage $\delta^{15} \mathrm{~N}$ by almost $6 \%$ relative to non-mycorrhizal plants ${ }^{7}$.

Finally, the root distribution in the soil profiles according to different site conditions might contribute to the differences in foliage $\delta^{15} \mathrm{~N}$. Trees with shallower roots might absorb more ${ }^{15} \mathrm{~N}$-depleted $\mathrm{N}$ because soil $\delta^{15} \mathrm{~N}$ increases with the soil depth (Fig. 5). Moreover, differences in root distributions might be caused by variation in edaphic conditions, regardless of the plant species. For example, the root soil is only 20 to $30 \mathrm{~cm}$ deep at DXAL due to the existence of a permanent frozen layer, while soft soil, which is good for the growth and development of plant roots, is more than $100 \mathrm{~cm}$ deep at CBS. Differences due to plant species appear to be small in eastern China. The range of foliage $\delta^{15} \mathrm{~N}$ was $5.1 \%$ in our study, while the range of foliage $\delta^{15} \mathrm{~N}$ for a single tree species was also $5.0 \%$ in a narrower region in eastern China ${ }^{14}$.

\section{Methods}

Site description. The north-south transect of eastern China (NSTEC) extends from Hainan island to China's northern border, ranging from $108^{\circ} \mathrm{E}$ to $118^{\circ} \mathrm{E}$ at latitudes less than $40^{\circ} \mathrm{N}$, and from $118^{\circ} \mathrm{E}$ to $128^{\circ} \mathrm{E}$ at latitudes equal to or greater than $40^{\circ} \mathrm{N}$. The transect includes 25 provinces and covers nearly one third of the land area in China (Fig. 1). A vegetation sequence is distributed along the NSTEC, which includes cold-temperate coniferous forest, temperate mixed forests, warm-temperate deciduous broadleaved forest, subtropical evergreen coniferous forest, evergreen broadleaved forest and tropical rainforest from north to south. The NSTEC is driven mainly by thermal conditions, with gradients of precipitation, atmospheric nitrogen deposition and land use intensity, and it provides an ideal platform to research carbon, nitrogen and water cycles of forest ecosystems in East Asia's monsoon region $^{39}$. Along the NSTEC, we chose seven forests to characterise $\delta^{15} \mathrm{~N}$ values of different components of China's typical forest ecosystems, which included Dinghushan (DHS), Huitong (HT), Dagangshan (DGS), Donglingshan (DLS), Changbaishan (CBS), Liangshui (LS), and Daxinganling (DXAL) (Fig. 1). The specific characteristics of the sampling sites are described in Table 1.

Sample collection. From July to August 2008, foliage, litter, and mineral soil samples were collected in the seven representative forest ecosystems from north to south along the NSTEC. To eliminate any systematic deviation, only non-leguminous predominant species were selected as samples to characterise the representative forest ecosystems. Three mature individual trees of each dominant species with mid-range diameter at breast height were randomly selected in each of the forest stands for collecting foliage samples. Each tree was open-grown, with full southern sun exposure. Fully mature leaves were sampled from the tips of south-facing branches in the lower crown of each tree by a tall tree trimmer. Foliage samples were collected from three individuals of each plant species and then combined into one sample.

Three sets of litter samples, comprising the $\mathrm{O}_{\mathrm{i}}$ horizon and the $\mathrm{O}_{\mathrm{ea}}$ horizon, were randomly sampled with a trowel within a $5 \mathrm{~cm}$ radius. In addition, three sets of mineral soil profile samples (5-6 m apart) were collected from three depths (0-10, $10-20$, and $20-40 \mathrm{~cm}$ ) with a $5 \mathrm{~cm}$ diameter auger. To reduce the impact of spatial heterogeneity, the soil at each depth was collected from three cores (holes, approximately 0.5-1.0 m apart) using a soil corer for each set of samples.

Foliage and litter samples were dried to constant weight at $65^{\circ} \mathrm{C}$. Mineral soils were air dried at room temperature and then sieved through a $2-\mathrm{mm}$ sieve to remove roots, 
gravel and stones. All samples were ground into a fine powder with a planetary mill and stored in glassware. Plant and soil samples were oven dried at $65^{\circ} \mathrm{C}$ for $24 \mathrm{~h}$ before analysis. In total, we obtained 48 foliage samples from 15 species, 42 litter samples, and 63 soil samples from the seven natural forest ecosystems.

$\mathbf{N}$ concentrations and $\boldsymbol{\delta}^{15} \mathrm{~N}$ analysis. Nitrogen concentrations and $\delta^{15} \mathrm{~N}$ values were determined simultaneously with an automatic, online elemental analyser (Flash EA1112, ThermoFinnigan, Milan, Italy) coupled to an isotope ratio mass spectrometer (IRMS) (Finnigan MAT 253, Thermo Electron, Bremen, Germany). The standard deviation of 10 repeated samples was $0.396 \%$. The results of the IRMS measurement are given in $\delta$ notation. $\delta$ values of isotopes of ${ }^{15} \mathrm{~N}$ were expressed in units of per mil (\%o), and calculated as follows,

$$
\delta(\%)=\left(\frac{R_{\text {sample }}}{R_{\text {standard }}}-1\right) \times 1000
$$

Where $R_{\text {sample }}$ and $R_{\text {standard }}$ are the nitrogen isotopic ratios $\left({ }^{15} \mathrm{~N} /{ }^{14} \mathrm{~N}\right)$ of the samples and standard, respectively. A positive or negative $\delta^{15} \mathrm{~N}$ value indicates the enrichment or depletion, respectively, of the heavy isotope relative to the light isotope, with respect to atmospheric $\mathrm{N}_{2}$.

Statistical analysis. The sample differences of $\delta^{15} \mathrm{~N}$ values and $\mathrm{N}$ concentrations were tested with analysis of variance (ANOVA). Comparison of the means was performed using Tukey's HSD test. The relationships between foliage or soil $\delta^{15} \mathrm{~N}$ and environmental or geographical variables were evaluated using Pearson correlation coefficient. Step regression analysis was used to select the key environmental factors contributing to variability in foliage $\delta^{15} \mathrm{~N}$. All analyses were conducted by SPSS software package (SPSS for Windows, Version 13.0, Chicago, IL, USA). Statistically significant differences were determined by $p<0.05$ unless stated otherwise.

1. Pardo, L. et al. Natural abundance ${ }^{15} \mathrm{~N}$ in soil and litter across a nitrate-output gradient in New Hampshire. For. Ecol. Manag. 251, 217-230 (2007).

2. Robinson, D. ${ }^{15} \mathrm{~N}$ as an integrator of the nitrogen cycle. Trends in Ecol. Evol. 16, 153-162 (2001).

3. Sah, S. P., Rita, H. \& Ilvesniemi, H. ${ }^{15} \mathrm{~N}$ natural abundance of foliage and soil across boreal forests of Finland. Biogeochemistry 80, 277-288 (2006).

4. Högberg, P. Tansley review No $95-{ }^{15} \mathrm{~N}$ natural abundance in soil-plant systems. New Phytol. 137, 179-203 (1997).

5. Hoch, M. P., Fogel, M. L. \& Kirchman, D. L. Isotope fractionation during ammonium uptake by marine microbial assemblages. Geomicrobiol. J. 12, 113-127 (1994).

6. Mariotti, A., Mariotti, F., Champigny, M. L., Amarger, N. \& Moyse, A. Nitrogen isotope fractionation associated with nitrate reductase activity and uptake of $\mathrm{NO}_{3}{ }^{-}$by Pearl Millet. Plant Physiol. 69, 880-884 (1982).

7. Craine, J. M. et al. Global patterns of foliage nitrogen isotopes and their relationships with climate, mycorrhizal fungi, foliage nutrient concentrations, and nitrogen availability. New Phytol. 183, 980-992 (2009).

8. Cheng, W., Chen, Q., Xu, Y., Han, X. \& Li, L. Climate and ecosystem ${ }^{15} \mathrm{~N}$ natural abundance along a transect of Inner Mongolian grasslands: Contrasting regional patterns and global patterns. Global Biogeochem. Cycles 23, GB2005, doi: 10.1029/ 2008GB003315 (2009).

9. Pardo, L. H. et al. Regional assessment of $\mathrm{N}$ saturation using foliage and $\operatorname{root} \delta^{15} \mathrm{~N}$. Biogeochemistry 80, 143-171 (2006).

10. Martinelli, L. A. et al. Nitrogen stable isotopic composition of leaves and soil: Tropical versus temperate forests. Biogeochemistry 46, 45-65 (1999).

11. Amundson, R. et al. Global patterns of the isotopic composition of soil and plant nitrogen. Global Biogeochem. Cycles 17, doi: 10.1029/2002gb001903 (2003).

12. Kitayama, K. \& Iwamoto, K. Patterns of natural $15 \mathrm{~N}$ abundance in the leaf-to-soil continuum of tropical rain forests differing in $\mathrm{N}$ availability on Mount Kinabalu, Borneo. Plant Soil 229, 203-212 (2001).

13. Wang, A. et al. Variations in nitrogen-15 natural abundance of plant and soil systems in four remote tropical rainforests, southern China. Oecologia 174, 567-580 (2014).

14. Kang, H. Z. et al. Variation in foliage delta(15)N among oriental oak (Quercus variabilis) stands over eastern China: Patterns and interactions. J. Geochemical Explora. 110, 8-14 (2011).

15. Yu, G. R. et al. Overview of ChinaFLUX and evaluation of its eddy covariance measurement. Agric. For. Meteorol. 137, 125-137 (2006).

16. Sheng, W. P. et al. Monitoring nitrogen deposition in typical forest ecosystems along a large transect in China. Environ. Moni. Assess. 185, 833-844 (2013).

17. Nadelhoffer, K. \& Fry, B. Nitrogen isotope studies in forest ecosystems. 22-24 (Blackwell Scientific Publications, Boston, MA, USA. 1994).

18. Hobbie, E. A. \& Hobbie, J. E. Natural abundance of ${ }^{15} \mathrm{~N}$ in nitrogen-limited forests and tundra can estimate nitrogen cycling through mycorrhizal fungi: A review. Ecosystems 11, 815-830 (2008).

19. Högberg, P. et al. ${ }^{15} \mathrm{~N}$ abundance of surface soils, roots and mycorrhizas in profiles of European forest soils. Oecologia 108, 207-214 (1996).

20. Cheng, S. L., Fang, H. J., Yu, G. R., Zhu, T. H. \& Zheng, J. J. Foliage and soil ${ }^{15} \mathrm{~N}$ natural abundances provide field evidence on nitrogen dynamics in temperate and boreal forest ecosystems. Plant Soil 337, 285-297 (2010).
21. Fang, H. J. et al. Effects of multiple environmental factors on $\mathrm{CO}_{2}$ emission and $\mathrm{CH}_{4}$ uptake from old-growth forest soils. Biogeosciences 7, 395-407 (2010).

22. Shearer, G. \& Kohl, D. H. $\mathrm{N}_{2}$ fixation in field settings - estimations based on natural ${ }^{15} \mathrm{~N}$ abundance. Aust. J. Plant Physiol. 13, 699-756 (1986).

23. Miller, A. E., Bowman, W. D. \& Suding, K. N. Plant uptake of inorganic and organic nitrogen: Neighbor identity matters. Ecology 88, 1832-1840 (2007).

24. Xu, X. L. et al. Spatio-temporal variations determine plant-microbe competition for inorganic nitrogen in an alpine meadow. J. Ecol. 99, 563-571 (2011).

25. Fang, Y. T. et al. Nitrogen deposition and forest nitrogen cycling along an urbanrural transect in southern China. Global Change Biol. 17, 872-885 (2011).

26. Galloway, J. N. et al. Transformation of the nitrogen cycle: Recent trends, questions, and potential solutions. Science 320, 889-892 (2008).

27. Hastings, M. G., Jarvis, J. C. \& Steig, E. J. Anthropogenic impacts on nitrogen isotopes of ice-core nitrate. Science 324, 1288-1288 (2009).

28. Xiao, H. Y. \& Liu, C. Q. Sources of nitrogen and sulfur in wet deposition at Guiyang, southwest China. Atmos. Environ. 36, 5121-5130 (2002).

29. Zhang, Y., Liu, X., Fangmeier, A., Goulding, K. \& Zhang, F. Nitrogen inputs and isotopes in precipitation in the North China Plain. Atmos. Environ. 42, 1436-1448 (2008).

30. Jia, G. \& Chen, F. Monthly variations in nitrogen isotopes of ammonium and nitrate in wet deposition at Guangzhou, south China. Atmos. Environ. 44, 2309-2315 (2010).

31. Xiao, H. Y., Tang, C. G., Xiao, H. W., Liu, X. Y. \& Liu, C. Q. Stable sulphur and nitrogen isotopes of the moss $<\mathrm{i}>$ Haplocladium microphyllum $</ \mathrm{i}>$ at urban, rural and forested sites. Atmos. Environ. 44, 4312-4317 (2010).

32. Kuang, Y. W. et al. Nitrogen deposition influences nitrogen isotope composition in soil and needles of Pinus massoniana forests along an urban-rural gradient in the Pearl River Delta of south China. J. Soils Sediments 11, 589-595 (2011).

33. Aber, J. D. et al. Is nitrogen deposition altering the nitrogen status of northeastern forests? BioScience 53, 375-389 (2003)

34. Elliott, E. M. et al. Nitrogen isotopes as indicators of $\mathrm{NO}_{\mathrm{x}}$ source contributions to atmospheric nitrate deposition across the Midwestern and northeastern United States. Environ. Sci. Technol. 41, 7 (2007).

35. Gundersen, P., Emmett, B. A., Kjønaas, O. J., Koopmans, C. J. \& Tietema, A. Impact of nitrogen deposition on nitrogen cycling in forests: a synthesis of NITREX data. Forest Ecol. Manag. 101, 37-55 (1998).

36. Aerts, R. The role of various types of mycorrhizal fungi in nutrient cycling and plant competition. Ecol. Studies 157, 117-134 (2003).

37. Nadelhoffer, K. J. \& Raich, J. W. Fine Root Production Estimates and Belowground Carbon Allocation in Forest Ecosystems. Ecology 73, 1139-1147 (1992).

38. Yang, X. et al. Diversity of arbuscular mycorrhizal fungi in Dahurian Larch forest in Da Hinggan Ling Mountains. Chin. J. Ecol. (in Chinese) 29, 504-510 (2010).

39. Yu, G. R. et al. Environmental controls over carbon exchange of three forest ecosystems in eastern China. Global Change Biol. 14, 2555-2571 (2008).

40. Zhang, Y. et al. Spatial and temporal variation of atmospheric nitrogen deposition in North China Plain. Acta Ecol. Sinica (in Chinese) 26, 1633-1639 (2006).

41. Zhou, C., Ouyang, H., Pei, Z. \& Xu, X. Net soil nitrogen mineralization in Chinese forest ecosystems. Acta Phytoecol. Sinica 27, 170-176 (2003).

\section{Acknowledgments}

We gratefully acknowledge the staff in Dinghushan, Huitong, Dagangshan, Donglingshan, Changbaishan, Liangshui, and Daxinganling forest ecosystem research stations for access and permission to their study sites. This study was financially supported by the National Basic Research Program of China (2010CB833504), the National Natural Science Foundation of China (31290221, 31100356 and 31000235), the Strategic Program of State Eco-environmental Investigation and Evaluation in China (Grant No. STSN-02-03), and the China Postdoctoral Science Foundation (2012M510042). We also thank Drs. Nianpeng $\mathrm{He}$ and Xingliang $\mathrm{Xu}$ for their suggestions for the manuscript.

\section{Author contributions}

W.S., G.Y. and H.F. conceived the study. W.S. carried out the experiments, performed the data analyses and wrote the manuscript. Y.L. assisted with the experiments. Q.W., Z.C. and L.Z. reviewed the manuscript.

\section{Additional information}

Competing financial interests: The authors declare no competing financial interests.

How to cite this article: Sheng, W.P. et al. Regional patterns of ${ }^{15} \mathrm{~N}$ natural abundance in forest ecosystems along a large transect in eastern China. Sci. Rep. 4, 4249; DOI:10.1038/ srep04249 (2014).

c) (i) $\odot$ This work is licensed under a Creative Commons Attribution-

By NG No NonCommercial-NoDerivs 3.0 Unported license. To view a copy of this license, visit http://creativecommons.org/licenses/by-nc-nd/3.0 